\title{
Analysis of Financial Statement of NRC Agro with Special Reference to Goods and Service Tax
}

Dr. Nalla Bala Kalyan ${ }^{1}$, Toopalli Sirisha ${ }^{2}$

${ }^{1}$ Associate Professor, Department of Management Studies, Sri Venkateswara College of Engineering Karakambadi Road, Tirupati, Andhra Pradesh, India

${ }^{2}$ Assistant Professor, Department of Management Studies, Sri Venkateswara College of Engineering Karakambadi Road, Tirupati, Andhra Pradesh, India

\begin{abstract}
The analysis of financial statements is an important aid to financial analysis. They provide information on how the firm has performed in the past and what is its current financial position. Financial analysis is the process of identifying the financial strengths and weakness of the firm from the available accounting data and financial statements. The analysis is done by establishing relationship between the different items of financial statements. The target of this paper is to examine the major features of GST. GST also known as the Goods and Services Tax is defined as the giant indirect tax structure premeditated to maintain and enhances the economic enlargement of a country. Service tax was a tax levied by Central Government of India on services provided or agreed to be provided excluding services covered under negative list and considering the Place of Provision of Services Rules, 2012 and collected as per Point of Taxation Rules, 2011 from the person liable to pay service tax. Person liable to pay service tax is governed by Service Tax Rules, 1994 he may be service provider or service receiver or any other person made so liable. It is an indirect tax wherein the service provider collects the tax on services from service receiver and pays the same to government of India. This paper has also focused on the impact of GST (Goods and Services Tax) will be on Indian Tax Scenario.
\end{abstract}

Keywords : Financial Statement, Goods, NRC AGRO, Service Tax, value added tax

\section{INTRODUCTION}

The financial statement provides the basic data for financial performance analysis. The financial statements provide a summarized view of the financial position and operations of a firm. Financial analysis refers to an assessment of the viability, stability and profitability of a business. Financial statement provides meaningful, useful and valuable information periodically regarding financial position and future prospects of the business concern. Various parties interested can utilize the information provided by the financial statement for analysis and interpretation. A tax is a mandatory financial charge or some other type of levy imposed upon a taxpayer (an individual or other legal entity) by a governmental organization in order to fund various public expenditures. A failure to pay, or evasion of or resistance to taxation, is punishable by law. Taxes consist of direct or indirect taxes and may be paid in money or as its labour equivalent. Most countries have a tax system in place to pay for public/common/agreed national needs and government functions: some levy a flat percentage rate of taxation on personal annual income, some on a scale based on annual income amounts, and some 
countries impose almost no taxation at all, or a very low tax rate for a certain area of taxation. Some countries charge a tax both on corporate income and dividends; this is often referred to as double taxation as the individual shareholder receiving this payment from the company will also be levied some tax on that personal income. There are two types of taxes that the Indian government levies on its citizens direct tax and indirect tax.

\section{Need for the Study}

Financial statement provides meaningful, useful and valuable information periodically regarding financial position and future prospects of the business concern. Various parties interested can utilize the information provided by the financial statement for analysis and interpretation.

To help management to understand the position, Progress and prospects of the business.

To study helps the management to know about its strength and weakness thereby it can be rectify its faults.

$>$ To help the management to raise the funds increases their order to earn more profit.

\section{Scope of the Study}

The area chosen for the study is Agro Industry : There are more than 10,000 Agro industries were located in India, out of them S R Agro (storage and DC) is selected for the research because Food is the main source for human being for living. There are various Agro industries are specialized in particular product but the selected company performing operating based on all varieties of food products to fulfill their customer demand on reliable prices. The study going to be done on this industry is Analysis of financial statement with special reference to Goods and Service Tax.

\section{Problem of the study}

The main problem of this study is the nature of the company is Agro based Industry. In that main problem of the study is a sudden change of Tax Rates in consumption of goods and services, how far it will bring changes in a financial statement of a company. For this kind of company they have more number of buyers and suppliers has adopted sudden tax rate change and impact in financial statement and position of a company to have sufficient cash in hand to pay creditors, advance payments for the shipment of goods both loading and unloading etc. If they fail to pay the goods will be demerged and will cause loss. Sudden change of tax rate how far it's good for the organization whether it affects financial position of a company and to manage current assets which can be easily converted into cash in order to avoid liquidity and to run day to day operations.

\section{Objectives of the Study}

$>$ To determine the "Analysis of Financial Statement of NRC Agro with special reference of GST"

$>$ How far it attracts the more Suppliers and Buyers to their products.

$>$ To identify the forces that influencing the Accounting System of a company.

$>$ To evaluate the profitability and liquidity position of the firm.

$>$ To study the short-term and long-term financial position of the company.

\section{Research Methodology}

\subsection{Research Design}

The project is based on descriptive research procedure using, which researcher has to use facts or information already available and analyze these to make a critical evaluation of the performance. 


\subsection{Analytical Tools for the Study}

The present study has taken into account Three years 2015-2018. The researcher for the purpose of analysis and interpretation the following tools have been need, Ratio analysis, Comparative balance sheet, Common size balance sheet, Correlation and Regression

\subsection{Data Analysis and Interpretation}

\subsubsection{Ratio Analysis}

Financial ratios are useful indicators of a firm's performance and financial situation. Most ratios can be calculated from information provided by the financial statements. Financial ratios can be used to analyze trends and to compare the firm's financials to those of other firms. In some cases, ratio analysis can predict future bankruptcy. Financial ratios can be classified according to the information they provide. The following types of ratios frequently are used.

\section{Current Ratio}

The current ratio is the ratio of total current asset to total current liabilities. This ratio is an indicator of the firms' commitment to meet its short term liabilities. The current ratio is an index of the concern's financial stability since it shows the extent of the working capital which is the amount by which the current assets exceeds the current liabilities. Current Ratio $=$ Current Assets $/$ Current Liabilities

\section{Table 1: Current Ratio}

\begin{tabular}{cccc}
\hline Year & Current assets (Rs) & Current liabilities (Rs) & Ratio (In Times) \\
\hline $\mathbf{2 0 1 4 - 2 0 1 5}$ & 16130816 & 2126225 & 7.58 \\
$\mathbf{2 0 1 5}-2016$ & 16917660 & 3761457 & 4.49 \\
$\mathbf{2 0 1 6}-2017$ & 55788615 & 17731422 & 3.14 \\
$\mathbf{2 0 1 7 - 2 0 1 8}$ & $\mathbf{7 8 8 2 5 7 9 2}$ & 34365356 & 2.29 \\
\hline
\end{tabular}

Source: balance sheet

\section{Interpretation}

It is observed that the ratio is at the dissatisfactory level when compared to the previous year. It was low in the year 2017-2018 with 2.29 times and high in the year 3.14 times. At last the ratio was decreased in the year 2016-2017 with 2.29 times because of the current asset value drastically decreased.

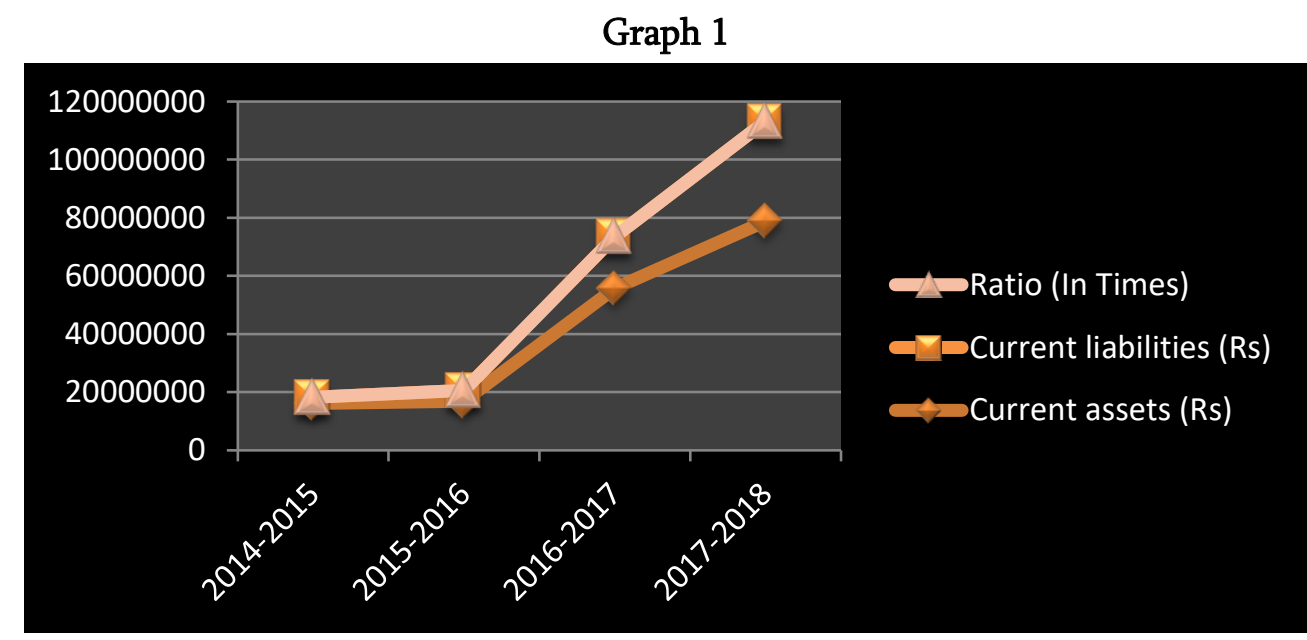




\section{Liquidity Ratio}

The liquidity ratio is the ratio between quick current asset and current liabilities. The term quick asset refers to current assets which can be converted into cash immediately or at a short notice without diminution of value .Current asset including cash and bank balance short term marketable securities debtors or receivable.

\section{Liquidity Ratio $=$ Liquid Asset $/$ Current Liabilities}

Table 2: Liquidity Ratio (In Crores)

\begin{tabular}{cccc}
\hline Year & Liquid Asset (Rs) & Current Liabilities (Rs) & Ratio (In Times) \\
\hline $2014-2015$ & 198920 & 2126225 & 0.09 \\
$2015-2016$ & 227128 & 3761457 & 0.06 \\
$2016-2017$ & 580612 & 17731422 & 0.03 \\
$2017-2018$ & 1544233 & 34365356 & 0.04 \\
\hline
\end{tabular}

Source : Balance Sheet

\section{Interpretation}

From the above table is inferred that ratio was high in the year 2017-2018 with 0.04 times and low in the year 2016-2017 with 0.03 times. The ratio was increased in the year 2017-2018 with 0.04 times due to the increased of liquidity asset.

\section{Graph 2: Liquidity Ratio}

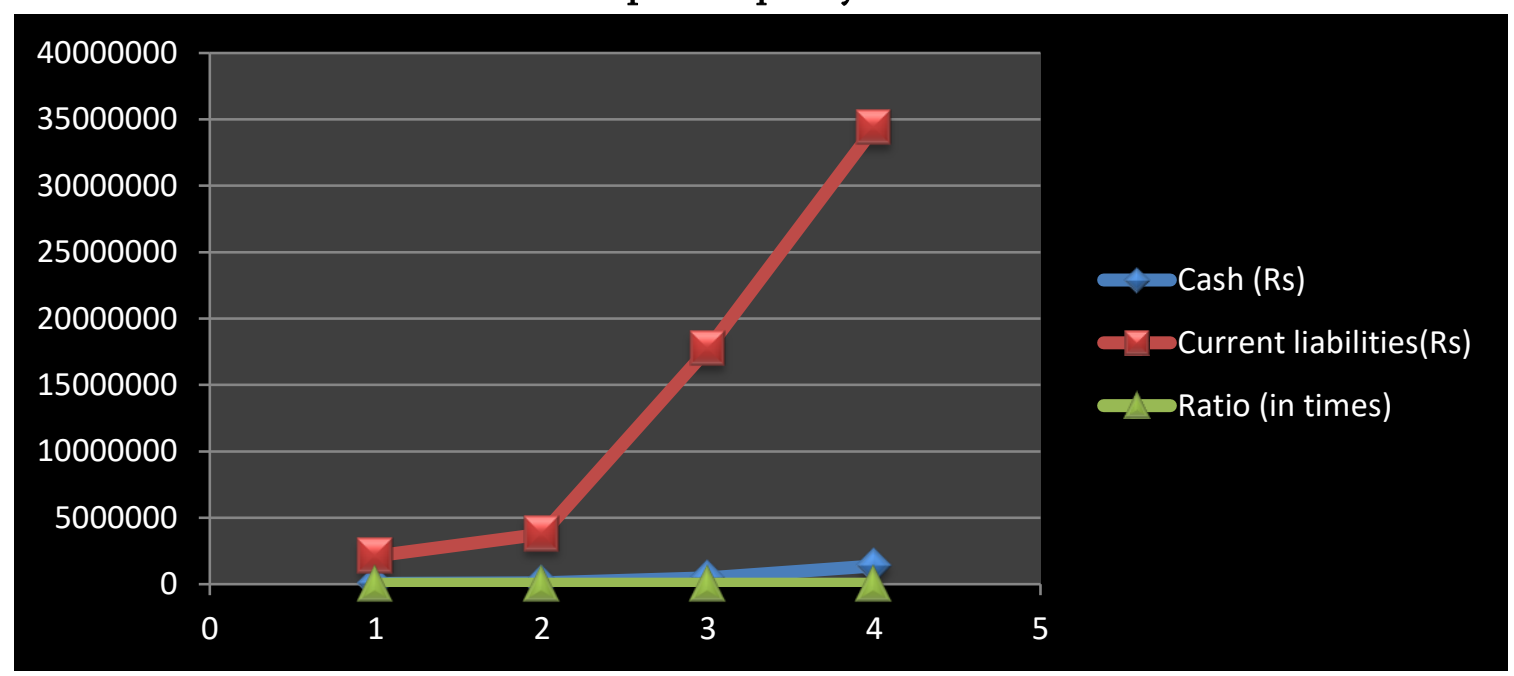

\section{Debtor's Turnover Ratio}

A concern may sell goods on cash as well as on credit. Credit is one of the important elements of sales promotion. The volume of sales can be increased by following a liberal credit policy. The effect of a liberal credit policy may result in tying up substantial funds of a firm in the form of trade debtors or receivable. Trade debtors are expected to be converted into cash within a short perio $\mathrm{d}$ of time and are included in current asset. Hence the liquidity position of concern to pay its short term obligations in time obligations in time depends upon the quality of its trade debtors. 
Debtors Turnover Ratio $=$ Sales $/$ Sundry Debtors

Table 3: Debtor's Turnover Ratio

\begin{tabular}{cccc}
\hline Year & Sales (Rs) & Sundry debtors (Rs) & Ratio (in times) \\
\hline $2014-2015$ & 74887994 & 5548796 & 13.49 \\
$2015-2016$ & 95783548 & 7046416 & 13.59 \\
$2016-2017$ & 268483001 & 18263557 & 14.7 \\
$2017-2018$ & 248045250 & 21355066 & 11.61 \\
\hline
\end{tabular}

Source: balance sheet

\section{Interpretation}

It is observed that the ratio is at the satisfactory level where it was high in the year 2016-2017 with 14.7 times and low in the year 2017- 2018 with 11.61 times. At present the ratio is decreased due to the increased of sundry debtors in the year (2017-2018).

\section{Graph 3}

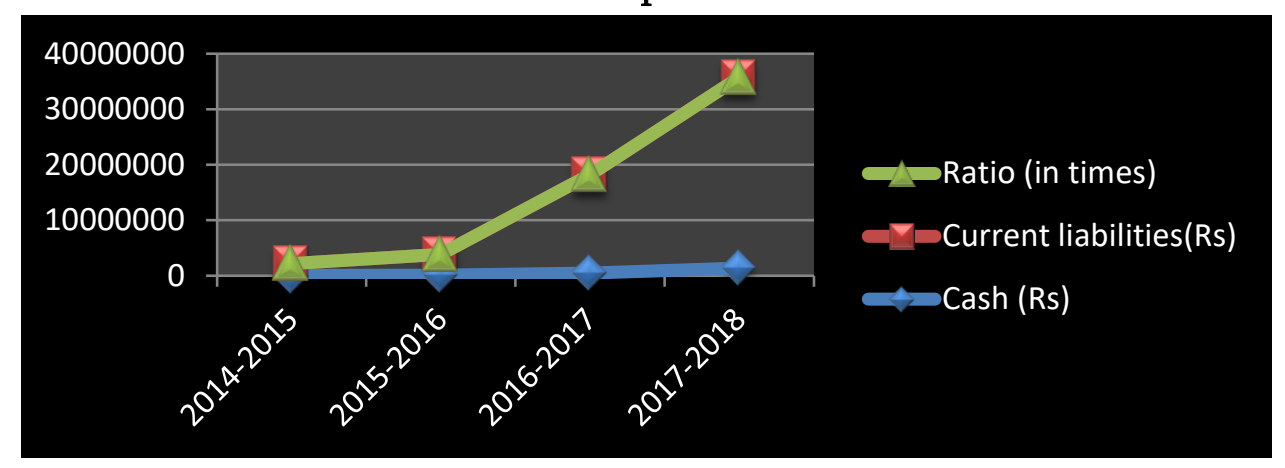

\section{Debt Collection Period}

The term debtor collection period indicates the average time taken to collect trade debts. In other words a reducing period of time is an indicator of increasing efficiency. It enables the enterprise to compare the real collection period with the granted/theoretical credit period.

\section{Average Collection Period = 365 Days / Debtors Turnover Ratio}

Table 4

\begin{tabular}{cccc}
\hline Year & Days in a year & Debtor turnover ratio & Period \\
\hline $2014-2015$ & 365 & 13.49 & 27.05 \\
\hline $2015-2016$ & 365 & 13.59 & 26.85 \\
$2016-2017$ & 365 & 14.7 & 24.82 \\
\hline $2017-2018$ & 365 & 11.61 & 31 \\
\hline
\end{tabular}

Source : balance sheet

Interpretation It is observed that the debtor collection period is less in the year $2016-2017,24$ days and its maximum in the period 2017 - 2018, 31 days. 


\section{Graph 4}

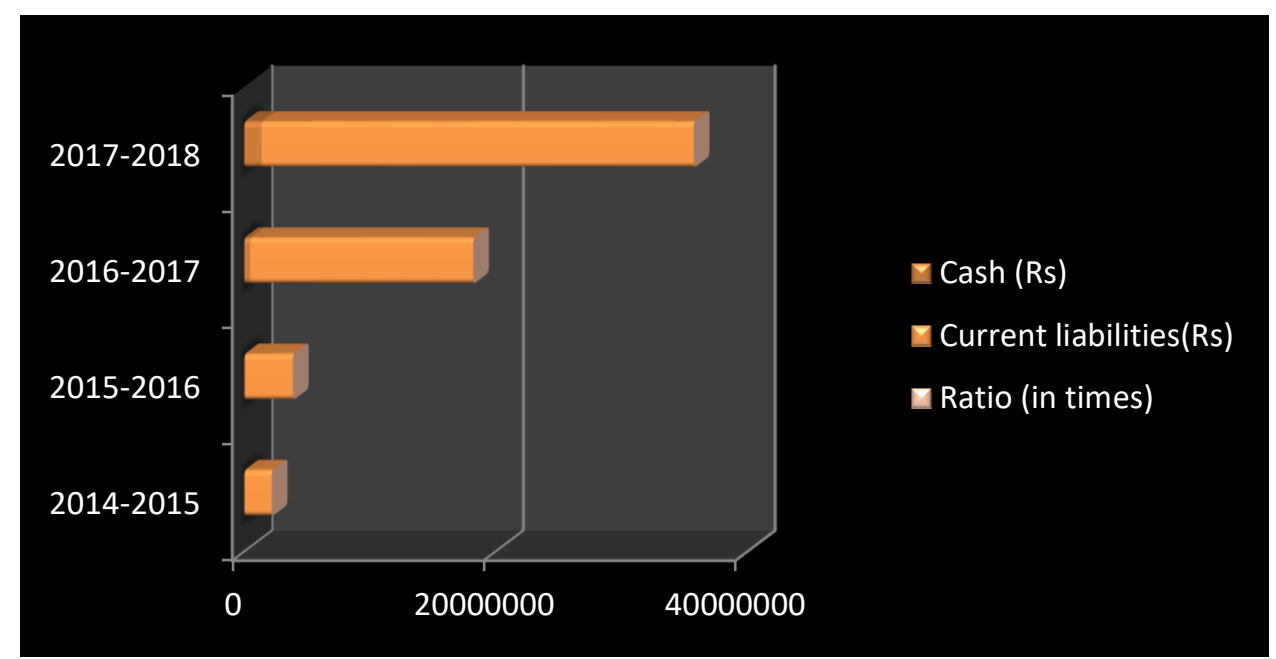

\section{Creditors Turnover Ratio}

A short term liquidity measure used to quantify the rate at which a company pays off its suppliers. Creditor's turnover ratio is also called as 'Accounts payable turnover ratio'. It is calculated by taking the total purchases made from suppliers and dividing it by the average accounts payable amount during the same period. Accounts payable turnover ratio is an accounting liquidity metric that evaluates how fast a company pays off its creditors or suppliers. The ratio shows how many times in a given period a company pays its average accounts payable. An accounts payable turnover ratio measures the number of times a company pays its suppliers during a specific accounting period.

\section{Turnover Ratio $=$ Total Sales $/$ Total Creditors}

Creditors or Average Collection Period = 365 Days / Creditors Turnover Ratio

Table 5

\begin{tabular}{ccccc}
\hline Years & Total Sales & Total Creditors & $\begin{array}{c}\text { Creditors Turnover } \\
\text { Ratio }\end{array}$ & Period \\
& & & 42.03 & 8 \\
\hline $2014-2015$ & 74887994 & 1781568 & 27.98 & 13 \\
$2015-2016$ & 95783548 & 3423109 & 19.48 & 18 \\
$2016-2017$ & 268483001 & 13780092 & 14.59 & 25 \\
\hline $2017-2018$ & 248045250 & 16998257 & & \\
\hline
\end{tabular}

Source: balance sheet

\section{Interpretation}

It is observed that the ratio is at the satisfactory level where it was high in the year 2014-2015 with 42.03 times and low in the year 2017- 2018 with 14.59 times. 
Graph 5

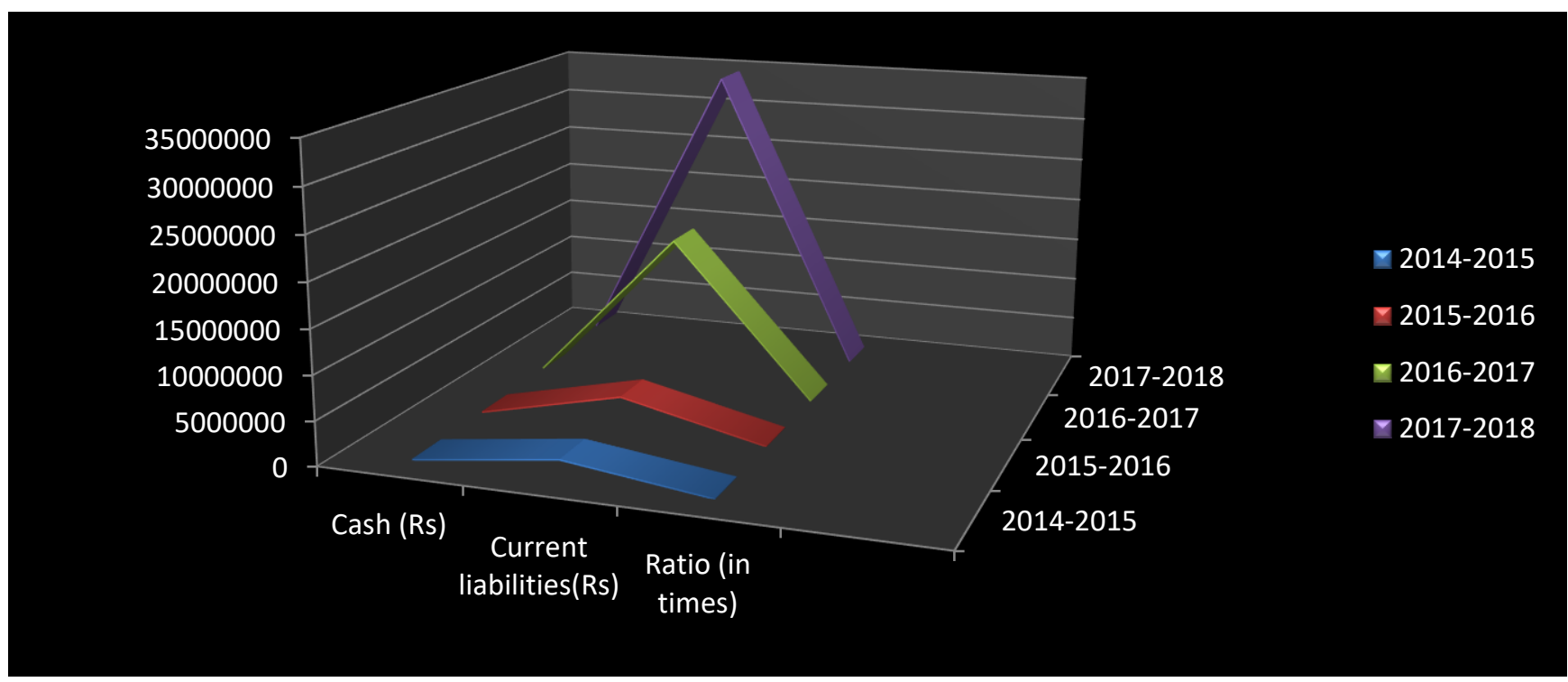

\section{Absolute Liquid Ratio}

In additional to computing current and quick ratio, some analysts also compute absolute liquid ratio to test the liquidity of the business. Absolute liquid ratio is computed by dividing the absolute liquid assets by current liability.

\section{Absolute Liquid Ratio = Absolute Liquid Assets / Current Liabilities}

Table 6

\begin{tabular}{cccc}
\hline \multicolumn{1}{c}{ Year } & $\begin{array}{c}\text { Absolute } \\
\text { Liquid Assets (Rs) }\end{array}$ & $\begin{array}{c}\text { Current } \\
\text { Liabilities(Rs) }\end{array}$ & Ratio (in times) \\
\hline $2014-2015$ & 57788 & 28448479 & 0.0020 \\
$2015-2016$ & 100954 & 39241988 & 0.0025 \\
$2016-2017$ & 468447 & 79981173 & 0.0058 \\
$2017-2018$ & 1377154 & 87539244 & 0.0157 \\
\hline
\end{tabular}

Source: balance sheet

\section{Interpretation}

From the above table it is clear that the absolute liquid ratio is high in the year 2017-2018with 0.015 times and low in the year 2014-2015 with 0.0020 times. The ratio has increased due to drastically increased liquid asset in the year 2017-2018 than the previous year 2016-2017liquid assets. 


\section{Graph 6}

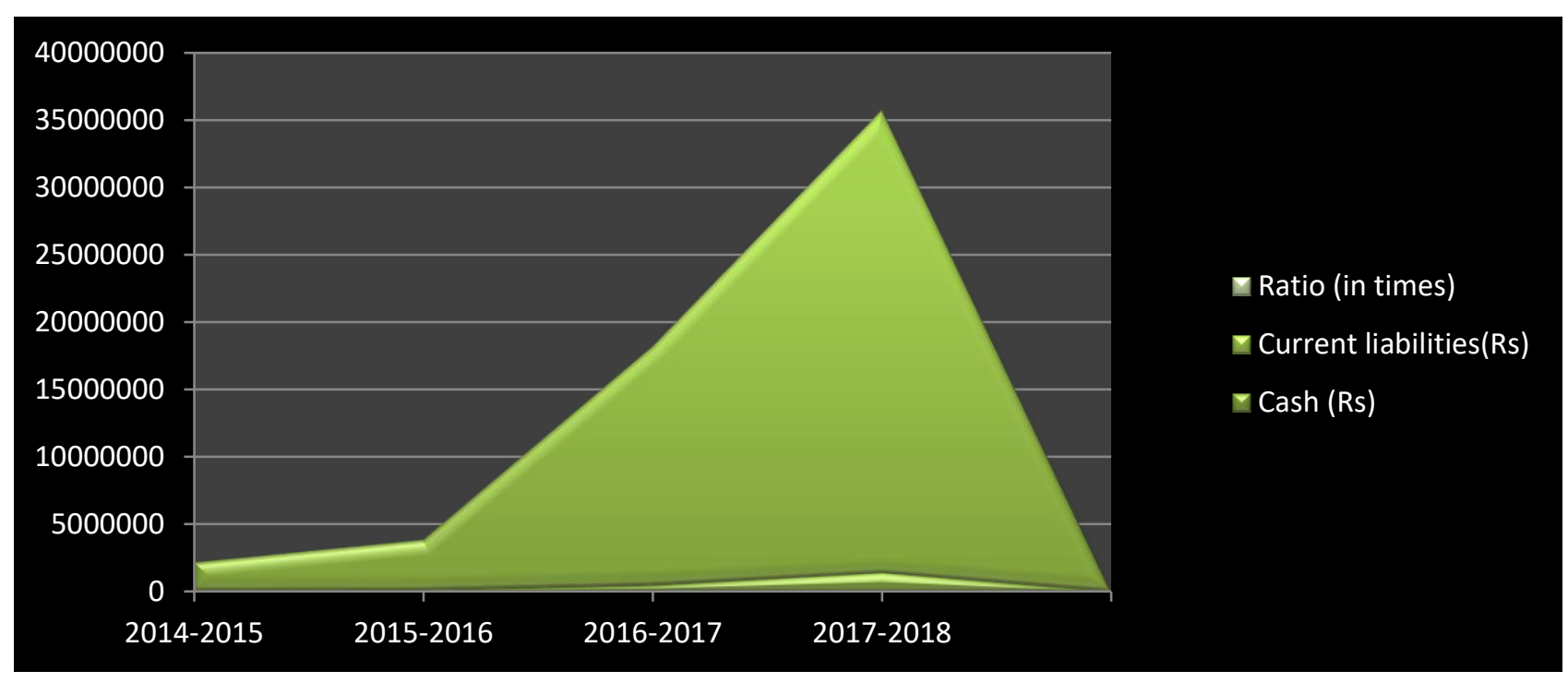

\section{Loans and Advances to Current Asset Ratio}

Loans and advances are utilized for making payment of current liabilities, wages and salaries of employees and also the tax liability of business. Current assets are those assets that are expected to be used (sold or consumed) within a year, unlike fixed assets. Current assets are shown on the balance sheet, and are listed in order of increasing liquidity. Usually stocks will be listed first, followed by debtors, with cash last. The current assets position of a company is important both for assessing its financial strength financial position (see current assets ratio) and for gauging its operational efficiency.

\section{Loans \& Advances to Current Assets Ratio = Loans \& Advances / Current Asset}

Table 7

\begin{tabular}{cccc}
\hline Year & Loans \& Advances(Rs) & Current Asset (Rs) & Ratio (In Times) \\
\hline $2014-2015$ & 26666911 & 16130816 & 1.65 \\
$2015-2016$ & 35818879 & 16917660 & 2.11 \\
$2016-2017$ & 66201081 & 55788615 & 1.18 \\
$2017-2018$ & 70540987 & 78825792 & 0.89 \\
\hline
\end{tabular}

Source: balance sheet

\section{Interpretation}

From the above table it is inferred that the ratio was high in the year 2015-2016 with 2.11 times and low in the year 2017-2018 with 0.89 times. The ratio was decreased in the year 2017-2018 from 2016-2017 due to the decrease of loans and advances. 


\section{Graph 8}

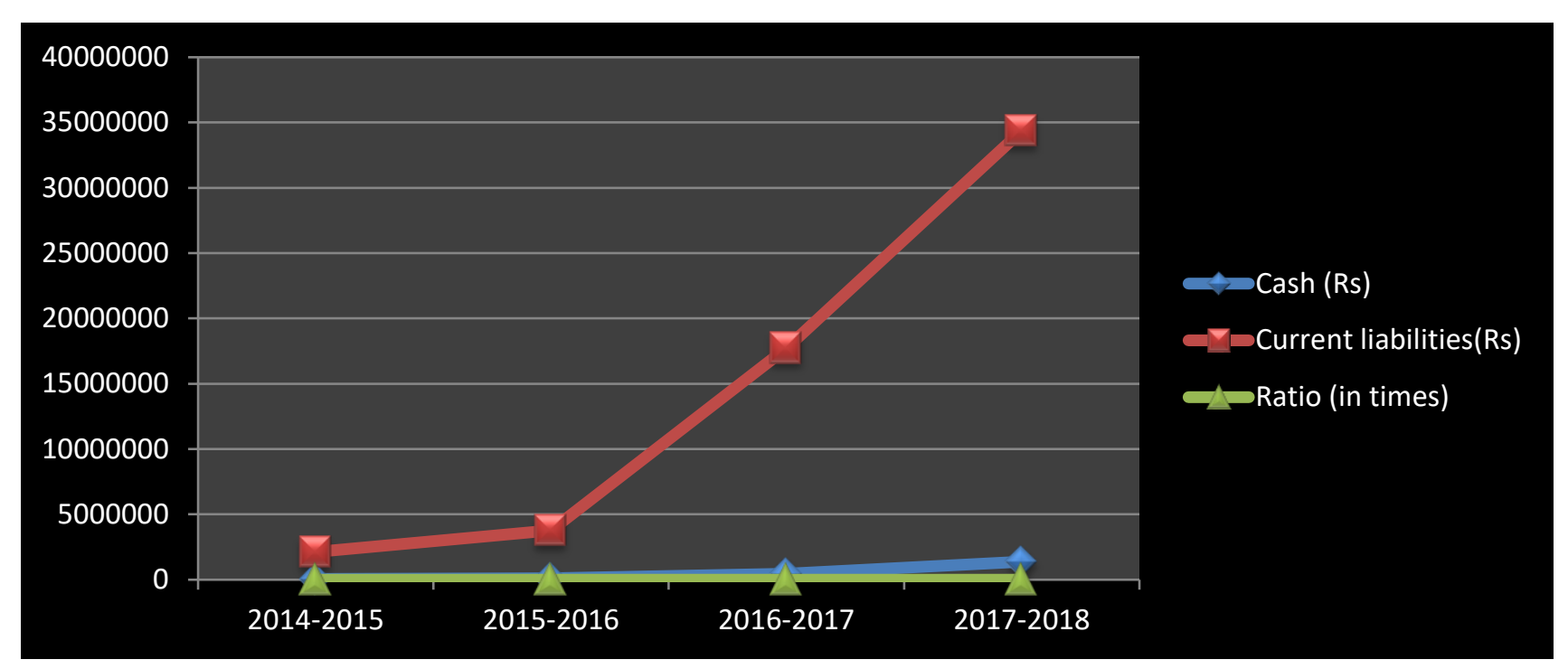

\section{Cash to Current Asset Ratio}

The cash to current asset ratio measures company liquidity, basing how liquid a company is by its cash. Important of cash to current assets is high or increasing cash to current asset ratio is generally a positive sign, showing the company's liquid assets represent a larger portion of its total current assets. It also indicates the company may be better able to convert its non-liquid assets.

\section{Cash to current asset ratio $=$ cash $/$ current asset}

Table 8

\begin{tabular}{cccc}
\hline Year & Cash $(\mathrm{Rs})$ & Current asset(Rs) & Ratio (in times) \\
\hline $2014-2015$ & 57788 & 16130816 & 0.003 \\
$2015-2016$ & 100954 & 16917660 & 0.0059 \\
$2016-2017$ & 468447 & 55788615 & 0.0084 \\
$2017-2018$ & 1377154 & 78825792 & 0.017 \\
\hline
\end{tabular}

Source: balance sheet

\section{Interpretation}

It is observed that the ratio was high in the year 2017-2018 with 0.017 times and low in the year 2016-2017 with 0.0084 times. At the present year 2017-2018 the ratio was in 0.017 times. It was drastically increased from 0.0084 times due to increase in the cash. 


\section{Graph 9}

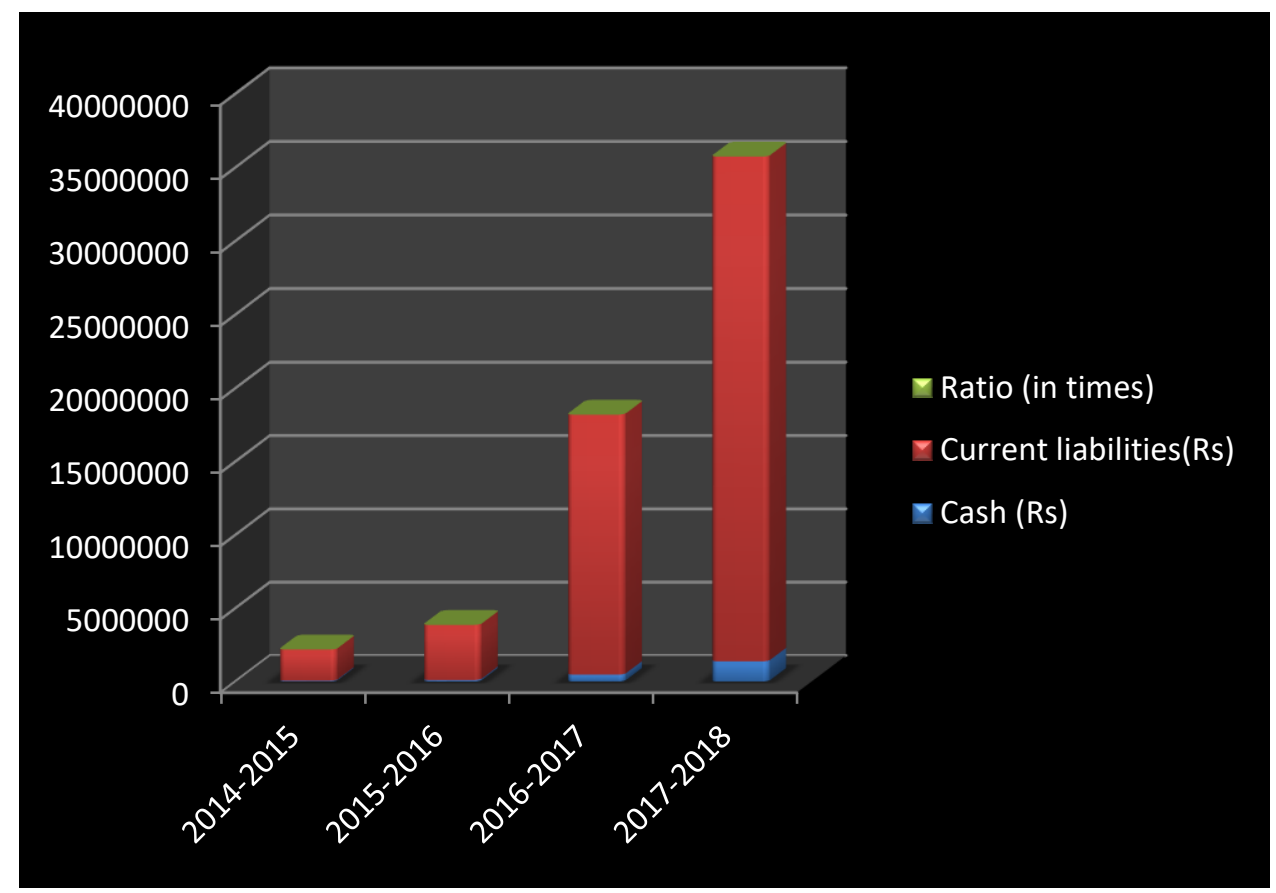

\section{Cash to Sales Ratio}

The cash to sales ratio indicates the number of times that cash turns over per year. High cash to sales ratio may indicate inadequate cash on hand. This may lead to financial problems if further financing is not available at reasonable prices.

\section{Cash to Sales Ratio $=$ Cash $/$ Sales}

Table 9

\begin{tabular}{clll}
\hline Year & Cash (Rs) & Sales (Rs) & Ratio (in times) \\
\hline $2014-2015$ & 57788 & 74887994 & 0.0007 \\
$2015-2016$ & 100954 & 95783548 & 0.00105 \\
$2016-2017$ & 468447 & 268483001 & 0.0017 \\
$2017-2018$ & 1377154 & 248045250 & 0.0055 \\
\hline
\end{tabular}

Source: balance sheet

\section{Interpretation}

It is observed that the ratio was high in the year 2017-2018 with 0.0055 times and low in the year 2016-2017 with 0.0017 times. Due to increase of sales value than the cash value, the ratio was decreased. 


\section{Graph 9}

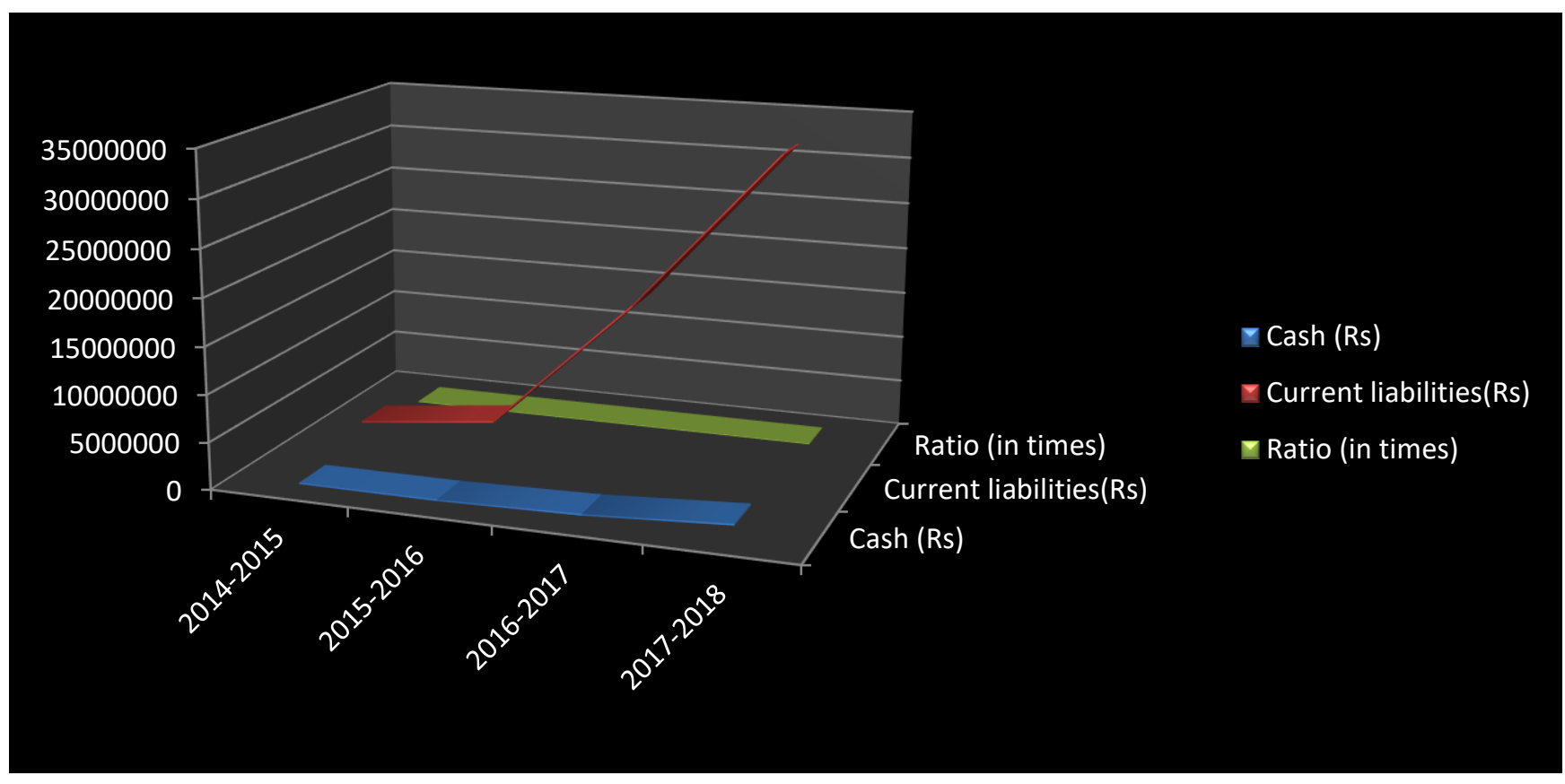

Cash Ratio: This indicates the relationship between cash and balances to current liability for the study period. It is calculated for comparing the cash with current liability. The higher proportion denotes idleness of cash, which affects the profitability position of the firm, and a low proportion of cash means shortage of cash liquidity.

\section{Cash Ratio $=$ Cash $/$ Current Liabilities}

Table 10

\begin{tabular}{cccc}
\hline Year & Cash (Rs) & Current liabilities(Rs) & Ratio (in times) \\
\hline $2014-2015$ & 57788 & 2126225 & 0.027 \\
$2015-2016$ & 100954 & 3761457 & 0.02684 \\
$2016-2017$ & 468447 & 17731422 & 0.02642 \\
$2017-2018$ & 1377154 & 34365356 & 0.04007 \\
\hline
\end{tabular}

Source : balance sheet

\section{Interpretation}

It is observed that the ratio is at the satisfactory level when compared to previous year it was high in the year 2017-2018 with 0.04007 times and it was low in the year 2016-2017 with 0.02642 times. Due to the increased of the cash value the ratio was high in the year 2017-2018. 


\section{Graph 10}

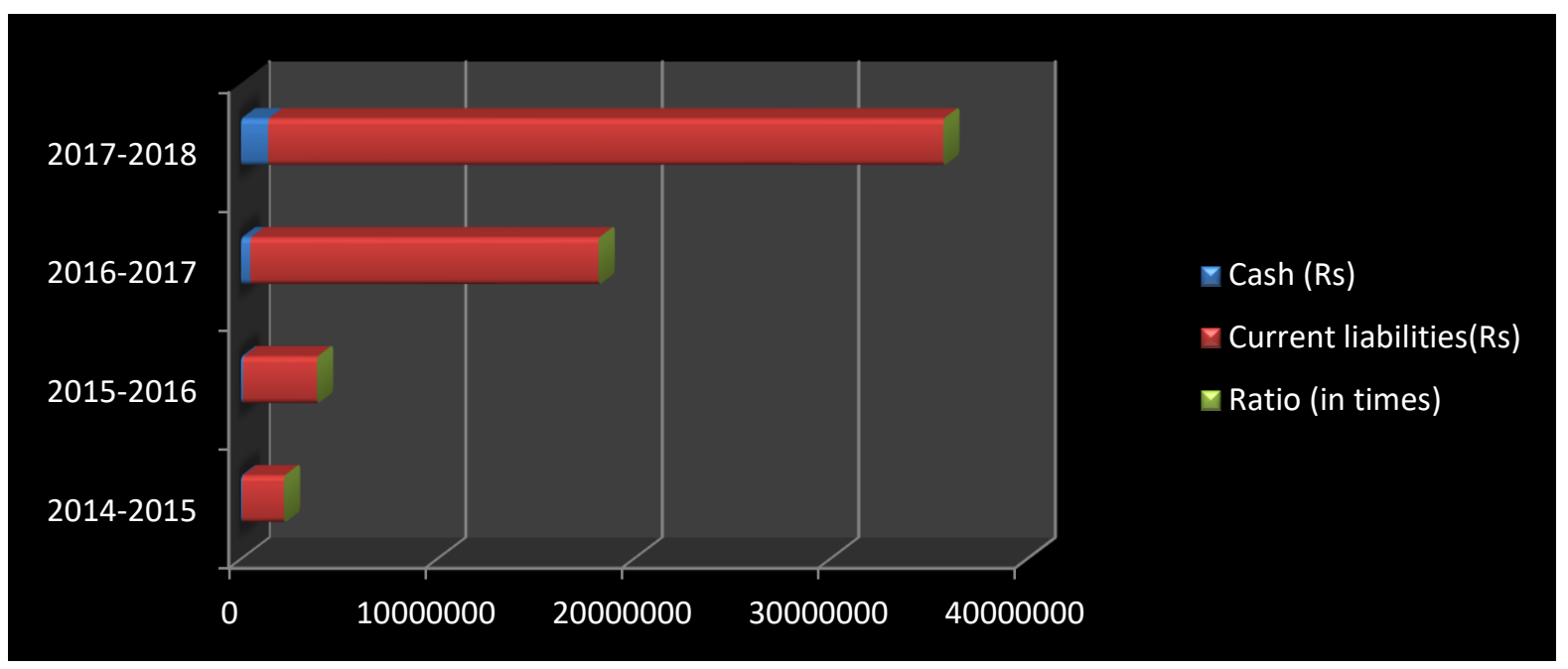

\subsection{Comparative Balance Sheet for Four Years}

Comparative Balance Sheet of NRC Agro Chennai, as on 31 st March 2015-2016

Table 11

\begin{tabular}{|c|c|c|c|c|}
\hline Particulars & $\begin{array}{l}2015 \\
(\mathrm{Rs})\end{array}$ & $\begin{array}{l}2016 \\
(\mathrm{Rs})\end{array}$ & $\begin{array}{l}\text { Increase/Decrease } \\
\text { In Amount (Rs) }\end{array}$ & $\begin{array}{l}\text { Increase/Decrease } \\
\text { In Percentage (\%) }\end{array}$ \\
\hline \multicolumn{5}{|l|}{ Assets } \\
\hline \multicolumn{5}{|l|}{ Current Assets } \\
\hline Cash in hand & 22496 & 68112 & 45616 & $202 \%$ \\
\hline Sundry Debtors & 5548796 & 7046416 & 1497620 & $26.9 \%$ \\
\hline Short Term Investments & 35292 & 32842 & -2450 & $-6.9 \%$ \\
\hline Total Current Assets (A) & 5606584 & 7147370 & 1540786 & $27.4 \%$ \\
\hline Fixed Assets (B) & 16130816 & 16917660 & 786844 & $4.87 \%$ \\
\hline Total Assets $(\mathrm{A}+\mathrm{B})$ & 21737400 & 24065030 & 2327630 & $10.7 \%$ \\
\hline \multicolumn{5}{|c|}{ Table 12} \\
\hline Particulars & $\begin{array}{l}2015 \\
\text { (Rs) }\end{array}$ & $\begin{array}{l}2016 \\
\text { (Rs) }\end{array}$ & $\begin{array}{l}\text { Increase/Decrease } \\
\text { In Amount (Rs) }\end{array}$ & $\begin{array}{l}\text { Increase/Decrease } \\
\text { In Percentage (\%) }\end{array}$ \\
\hline \multicolumn{5}{|l|}{ Liabilities } \\
\hline \multicolumn{5}{|l|}{ Current Liabilities } \\
\hline Sundry Creditors & 1781568 & 3423109 & 1641541 & $92 \%$ \\
\hline \multicolumn{5}{|l|}{ Amount due on Loan and } \\
\hline Advances & 26666911 & 35818879 & 9151968 & $34.3 \%$ \\
\hline Total Current Liabilities (A) & 28448479 & 39241988 & 10793509 & $37.9 \%$ \\
\hline Capital \&Reserve Funds (B) & 1848341 & 9268299 & -7419958 & $-80 \%$ \\
\hline Total Investments (C) & 62663 & 226900 & 164237 & $262 \%$ \\
\hline Total Liabilities (A+B+C) & 30359483 & 30200589 & -158894 & $-0.5 \%$ \\
\hline
\end{tabular}




\section{Interpretation}

Compared to 2015-16, Current assets have increase by $27.4 \%$ that Sundry debtors have increased $26.9 \%$ due to payment to employees and other parties. Cash in hand represent amount from central government has increased 202\% which shows less lending, also Current liabilities have increased by $37.9 \%$ mainly due to increase in checks and bill payables and security deposit received. Total investment has been raised by $262 \%$ which has been successfully invested in fixed assets.

\section{Table 13}

Comparative Balance Sheet of NRC Agro Chennai, as on 31 ${ }^{\text {st }}$ March 2016-2017

\begin{tabular}{lrrrr}
\hline Particulars & 2016(Rs) & 2017 (Rs) & $\begin{array}{l}\text { Increase/Decrease } \\
\text { In Amount (Rs) }\end{array}$ & $\begin{array}{l}\text { Increase/Decrease In } \\
\text { Percentage (\%) }\end{array}$ \\
\hline Assets & & & & \\
Current Assets & & & & \\
Cash in hand & 68112 & 267659 & 199547 & $159 \%$ \\
Sundry Debtors & 7046416 & 18263557 & 11217141 & $511 \%$ \\
Short Term Investments & 32842 & 200788 & 167946 & $162 \%$ \\
Total Current Assets (A) & 7147370 & 18732004 & 11584634 & $252 \%$ \\
Fixed Assets (B) & 16917660 & 59669591 & 42751931 & $225 \%$ \\
\hline Total Assets (A+B) & 24065030 & 78401595 & 54336565 & \\
\hline
\end{tabular}

Table 14

\begin{tabular}{|c|c|c|c|c|}
\hline Particulars & $2016(\mathrm{Rs})$ & 2017 (Rs) & $\begin{array}{l}\text { Increase/Decrease } \\
\text { In Amount(Rs) }\end{array}$ & $\begin{array}{c}\text { Increase/Decrease In } \\
\text { Percentage (\%) }\end{array}$ \\
\hline \multicolumn{5}{|l|}{ Liabilities } \\
\hline \multicolumn{5}{|l|}{ Current Liabilities } \\
\hline Sundry Creditors & 3423109 & 13780092 & 10356983 & $302 \%$ \\
\hline $\begin{array}{l}\text { Amount due on Loan and } \\
\text { Advances }\end{array}$ & 35818879 & 66201081 & 30382202 & $84.8 \%$ \\
\hline $\begin{array}{l}\text { Total Current Liabilities } \\
\text { (A) }\end{array}$ & 39241988 & 79981173 & 40739185 & $103 \%$ \\
\hline \multicolumn{5}{|l|}{ Capital \& Reserve } \\
\hline Funds (B) & -9268299 & 36100073 & 45368372 & $79.99 \%$ \\
\hline Total Investments (C) & 226900 & 944986 & 718086 & $316 \%$ \\
\hline Total Liabilities $(\mathrm{A}+\mathrm{B}+\mathrm{C})$ & 30200589 & 117026232 & 86825643 & $287 \%$ \\
\hline
\end{tabular}

\section{Interpretation}

Compared to 2016-17, Current assets have increase by 162\% that Sundry debtors have increased 159\% due to payment to employees and other parties. Cash in hand represent amount from central government has also increased 292\% which shows more lending, also Current liabilities have increased by 103\% mainly due to increase in checks and bill payables and security deposit reserved. Total investment has been raised by $316 \%$ which has been successfully invested in fixed assets. 
Table 15

Comparative Balance Sheet of NRC Agro Chennai, as on 31 ${ }^{\text {st }}$ March 2017-2018

\begin{tabular}{|c|c|c|c|c|}
\hline Particulars & $\begin{array}{l}2017 \\
(\mathrm{Rs})\end{array}$ & $\begin{array}{l}2018 \\
\text { (Rs) }\end{array}$ & $\begin{array}{c}\text { Increase/Decrease } \\
\text { In Amount (Rs) }\end{array}$ & $\begin{array}{l}\text { Increase/Decrease } \\
\text { In Percentage (\%) }\end{array}$ \\
\hline \multicolumn{5}{|l|}{ Assets } \\
\hline \multicolumn{5}{|l|}{ Current Assets } \\
\hline Cash in hand & 267659 & 549354 & 281695 & $105 \%$ \\
\hline Sundry Debtors & 18263557 & 21355066 & 3091509 & $16.9 \%$ \\
\hline Short Term Investments & 200788 & 827800 & 627012 & $312 \%$ \\
\hline Total Current Assets (A) & 18732004 & 22732220 & 4000216 & $21.3 \%$ \\
\hline Fixed Assets (B) & 59669591 & 61169935 & 1500344 & $2.5 \%$ \\
\hline Total Assets (A+B) & 78401595 & 83902155 & 5500560 & $7.01 \%$ \\
\hline \multicolumn{5}{|c|}{ Table 16} \\
\hline Particulars & 2017(Rs) & 2018 (Rs) & $\begin{array}{l}\text { Increase/Decrease I } \\
\text { In Amount (Rs) }\end{array}$ & $\begin{array}{l}\text { Increase/Decrease In } \\
\text { Percentage (\%) }\end{array}$ \\
\hline \multicolumn{5}{|l|}{ Liabilities } \\
\hline \multicolumn{5}{|l|}{ Current Liabilities } \\
\hline Sundry Creditors & 13780092 & 16998257 & \multirow[t]{2}{*}{3218165} & \multirow[t]{2}{*}{$23.3 \%$} \\
\hline $\begin{array}{l}\text { Amount due on Loan and } \\
\text { Advances }\end{array}$ & 66201081 & 70540987 & & \\
\hline \multicolumn{5}{|l|}{$\begin{array}{l}\text { Advances } \\
\text { Total }\end{array}$} \\
\hline Current Liabilities (A) & 79981173 & 87539244 & 7558071 & $9.43 \%$ \\
\hline \multicolumn{5}{|l|}{ Capital \& Reserve } \\
\hline Funds (B) & 36100073 & 26449860 & -9650213 & $-26.9 \%$ \\
\hline Total Investments (C) & 944986 & 1342800 & 397814 & $42.1 \%$ \\
\hline Total Liabilities $(\mathrm{A}+\mathrm{B}+\mathrm{C})$ & 117026232 & 115331904 & -1694328 & $-1.44 \%$ \\
\hline
\end{tabular}

\section{Interpretation}

Compared to 2017-18, Current assets have increase by $21.3 \%$ that Sundry debtors have increased $16.9 \%$ due to payment to employees and other parties. Cash in hand represent amount from central government has also decreased 105\% which shows less lending, also Current liabilities have increased by $9.43 \%$ mainly due to increase in checks and bill payables and security deposit reserved. Total investment has been decreased by $42.1 \%$ which has been unsuccessfully invested in fixed assets.

Table 17

Common Size Balance Sheet for Four Years

Common Size Balance Sheet of NRC Agro Chennai, as on 31 ${ }^{\text {st }}$ March 2015-2016

\begin{tabular}{lcccc}
\hline Particulars & 2015(Rs) & 2015(\%) & 2016(Rs) & 2016(\%) \\
\hline Assets & & & & \\
Current Assets & & & & \\
Cash in hand & 22496 & $0.10 \%$ & 68112 & $0.28 \%$
\end{tabular}




\begin{tabular}{|c|c|c|c|c|c|}
\hline Sundry Debtors & 5548796 & $25.53 \%$ & \multicolumn{2}{|c|}{7046416} & $29.28 \%$ \\
\hline Short Term Investments & 35292 & 0.16 & \multicolumn{2}{|c|}{32842} & $0.14 \%$ \\
\hline Total Current Assets (A) & 5606584 & $25.79 \%$ & \multicolumn{2}{|c|}{7147370} & $29.70 \%$ \\
\hline Fixed Assets (B) & 16130816 & $74.21 \%$ & \multicolumn{2}{|c|}{16917660} & $70.30 \%$ \\
\hline Total Assets (A+B) & 21737400 & $100 \%$ & \multicolumn{2}{|c|}{24065030} & $100 \%$ \\
\hline \multicolumn{6}{|c|}{ Table 18} \\
\hline Particulars & \multicolumn{2}{|r|}{ 2015(Rs) } & $2015(\%)$ & 2016(Rs) & $2016(\%)$ \\
\hline \multicolumn{6}{|l|}{ Liabilities } \\
\hline \multicolumn{6}{|l|}{ Current Liabilities } \\
\hline \multicolumn{2}{|l|}{ Sundry Creditors } & 1781568 & $5.87 \%$ & 3423109 & $7.02 \%$ \\
\hline \multicolumn{2}{|c|}{ Amount due on Loan and Advances } & 26666911 & $87.84 \%$ & 35818879 & $73.49 \%$ \\
\hline \multicolumn{2}{|c|}{ Total Current Liabilities (A) } & 28448479 & $93.71 \%$ & 39241988 & $80.52 \%$ \\
\hline \multicolumn{2}{|c|}{ Capital \&Reserve Funds (B) } & 1848341 & $6.09 \%$ & 9268299 & $19.02 \%$ \\
\hline \multicolumn{2}{|l|}{ Total Investments (C) } & 62663 & $0.21 \%$ & 226900 & $0.47 \%$ \\
\hline \multicolumn{2}{|l|}{ Total Liabilities $(\mathrm{A}+\mathrm{B}+\mathrm{C})$} & 30359483 & $100 \%$ & 48737187 & $100 \%$ \\
\hline
\end{tabular}

\section{Interpretation}

YEAR OF 2015 : In the sources of funds out in 2015 is 100\%, total current assets was $25.79 \%$, fixed asset was $74.21 \%$ in the application of funds in 2015 is $100 \%$, capital and reserve funds was $6.09 \%$ total current liabilities where by $93.714 \%$ and total investment was $0.21 \%$

YEAR OF 2016 : In the sources of funds out in 2016 is 100\%, total current assets was increased by $29.70 \%$, fixed asset was decreased by $70.30 \%$ in the application of funds in 2016 is $100 \%$, capital and reserve funds was increased by $19.02 \%$ total current liabilities where decreased by $80.52 \%$ and total investment was increased $0.47 \%$.

Table 19

Common Size Balance Sheet of NRC Agro Chennai, as on 31 ${ }^{\text {st }}$ March 2017-2018

\begin{tabular}{lrrrr}
\hline \multicolumn{1}{c}{ Particulars } & \multicolumn{1}{c}{ 2017(Rs) } & \multicolumn{1}{c}{$2017(\%)$} & 2018(Rs) & 2018(\%) \\
\hline Assets & & & & \\
Current Assets & & & & \\
Cash in hand & 267659 & $0.34 \%$ & 549354 & $0.65 \%$ \\
Sundry Debtors & 18263557 & $23.29 \%$ & 21355066 & $25.45 \%$ \\
Short Term Investments & 200788 & $0.26 \%$ & 827800 & $0.99 \%$ \\
Total Current Assets (A) & 18732004 & $23.89 \%$ & 22732220 & $27.09 \%$ \\
Fixed Assets (B) & 59669591 & $76.11 \%$ & 61169935 & $72.91 \%$ \\
Total Assets (A+B) & 78401595 & $100 \%$ & 83902155 & $100 \%$ \\
\hline
\end{tabular}


Table 20

\begin{tabular}{|c|c|c|c|c|}
\hline Particulars & 2017(Rs) & $2017(\%)$ & 2018(Rs) & $2018(\%)$ \\
\hline \multicolumn{5}{|l|}{ Liabilities } \\
\hline \multicolumn{5}{|l|}{ Current Liabilities } \\
\hline Sundry Creditors & 13780092 & $11.78 \%$ & 16998257 & $14.74 \%$ \\
\hline $\begin{array}{l}\text { Amount due on Loan } \\
\text { and Advances }\end{array}$ & 66201081 & $56.57 \%$ & 70540987 & $61.16 \%$ \\
\hline Total Current & & & & \\
\hline Liabilities (A) & 79981173 & $68.34 \%$ & 87539244 & $75.90 \%$ \\
\hline Capital \&Reserve & & & & \\
\hline Funds (B) & 36100073 & $30.85 \%$ & 26449860 & $22.93 \%$ \\
\hline Total Investments (C) & 944986 & $0.81 \%$ & 1342800 & $1.16 \%$ \\
\hline $\begin{array}{l}\text { Total Liabilities } \\
(\mathrm{A}+\mathrm{B}+\mathrm{C})\end{array}$ & 117026232 & $100 \%$ & 115331904 & $100 \%$ \\
\hline
\end{tabular}

Interpretation

YEAR OF 2017 : In the sources of funds out in 2017 is $100 \%$, total current assets was decreased $23.89 \%$, fixed asset was increased by $76.11 \%$ in the application of funds in 2017 is $100 \%$, capital and reserve funds was increased $30.85 \%$ total current liabilities where decreased by $68.34 \%$ and total investment is increased $0.81 \%$.

YEAR OF 2018 : In the sources of funds out in 2018 is $100 \%$, total current assets was increased by $27.09 \%$, fixed asset was decreased by $72.91 \%$ in the application of funds in 2018 is 100\%, capital and reserve funds was decreased by $22.93 \%$, total current liabilities where increased by $75.90 \%$, and total investment was increased $1.16 \%$.

\subsubsection{Correlation}

The degree of relationship between the variables under consideration is measured through correlation analysis. It is also known as simple linear correlation or product moment method. It is the most widely used method of discovering the extent of correspondence. The formula for finding correlation between variables is

$$
\mathrm{r}=\frac{\mathrm{n} \sum \mathrm{xy}-\sum \mathrm{x} \sum \mathrm{y}}{\sqrt{\mathrm{n} \sum \mathrm{x}^{2}}-\left(\sum \mathrm{x}\right)^{2} \sqrt{\mathrm{n} \sum \mathrm{y}^{2}-\left(\sum \mathrm{y}\right)^{2}}}
$$

Table Showing Correlation between Deprecation and Profit \Loss

\begin{tabular}{|c|r|r|}
\hline S. No & Depreciation & \multicolumn{1}{l|}{ Net Loss } \\
\hline 1 & $2,954,689$ & $1,035,120$ \\
\hline 2 & 845,542 & $4,473,135$ \\
\hline 3 & $3,006,554$ & $2,184,556$ \\
\hline 4 & $2,751,056$ & $1,895,926$ \\
\hline Total & $\mathbf{9 , 5 5 7 , 8 4 1}$ & $\mathbf{9 , 5 8 8 , 7 3 7}$ \\
\hline
\end{tabular}

\section{Interpretation}

Since the value of correlation coefficient between depreciation and Net Loss is $\mathbf{- 0 . 9 4 0}$ which indicates that there is a negative relationship between deprecation and Profit/Loss. This makes major drawback for Net Loss to the company.

\subsubsection{Regression}

Regression is a statistical measure used in finance, investing and other disciplines that attempts to determine the strength of the relationship between one dependent variable (usually denoted by $\mathrm{Y}$ ) and a series of other changing variables (known as independent variables). Regression helps investment and financial managers to value assets and understand 
the relationships between variables, such as commodity prices and the stocks of businesses dealing in those commodities.

\section{Null Hypothesis (H0):}

There is a positive relationship between the VAT Payable and Net Loss of a company.

\section{Alternative Hypothesis (H1):}

There is a negative relationship between the VAT Payable and Net Loss of a company.

\begin{tabular}{|c|r|r|}
\hline S. No & VAT Payable & \multicolumn{1}{l|}{ Net Loss } \\
\hline 1 & 83,394 & $1,035,120$ \\
\hline 2 & 111,448 & $4,473,135$ \\
\hline 3 & 130,800 & $1,895,926$ \\
\hline Total & 325,642 & $7,404,181$ \\
\hline
\end{tabular}

Summary Output

\begin{tabular}{|c|r|}
\hline $\begin{array}{c}\text { Regression } \\
\text { Statistics }\end{array}$ & \\
\hline Multiple R & 0.341538948 \\
\hline R Square & 0.116648853 \\
\hline $\begin{array}{c}\text { Adjusted R } \\
\text { Square }\end{array}$ & -0.766702293 \\
\hline Standard Error & 31681.83787 \\
\hline Observations & 3 \\
\hline
\end{tabular}

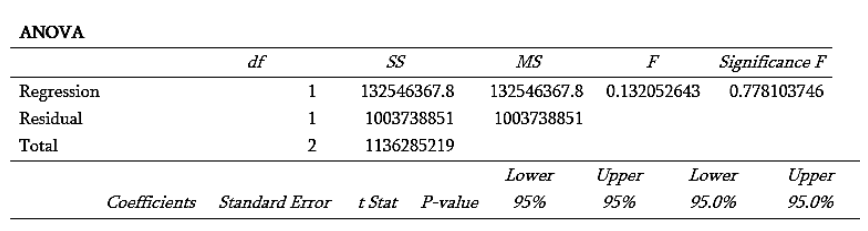

$\begin{array}{lllllllll}\text { Intercept } & 97316.38 & 35913.24119 & 2.7098 & 0.22507 & 359004.6 & 553637.38 & 359004.61 & 553637.38\end{array}$ \begin{tabular}{llllllllll} 
Net Loss & 0.004551 & 0.012522387 & 0.3634 & 0.7781 & 0.154561 & 0.1636625 & 0.1545615 & 0.16366253 \\
\hline
\end{tabular}

\section{Regression value $=0.116649$}

Value is positive so there is a positive relationship between the VAT Payable and Net Loss to the company.

\section{Interpretation}

Since value is 0.116649 so there is a positive relationship between the VAT Payable and Net Loss to the company. It is major reason causes Loss to the company.

Finally, NRC Agro has increasing their operation efficiency and expanding their business Activities all over India. In future this will results in Profit to their business. Faster conversion cycle of debtors or accounts receivables: faster rolling of money via debtors will keep the current ratio in control. At least the ratio will show a correct picture if the debtors are liquid. A constant follow up with the debtors can improve the collection from them. In the first dealing itself, the payment terms should be made clear and should negotiate credit period as low as possible. Pay off current liabilities: not only does the current ratio depend on current assets, it is equally dependent on the current liability which is the denominator. They should be paid off as often and as early as possible. It would decrease the level of current liabilities and therefore improve the current ratio. Early payments to creditors can save interest cost and earn discount which will have direct impact to the profits of the firm. Selloff unproductive assets: cash level can be increased by selling unused fixed assets. Otherwise the money is unnecessarily blocked into them and idle money accrues interest cost.

\section{VI.CONCLUSION}

Change is definitely never easy: The government is trying to smoothen the road to GST. It is important to take a leaf from global economies that have implemented GST before us, and who overcame the teething troubles to experience the advantages of having a unified tax system and easy input credits. GST came into effect in the middle of the financial year: As GST was implemented on the $1^{\text {st }}$ of July 2017, 
businesses followed the old tax structure for the first 3 months (April, May, and June), and GST for the rest of the financial year. Businesses may find it hard to get adjusted to the new tax regime, and some of them are running these tax systems parallels, resulting in confusion and compliance issues.GST will mean an increase in operational costs: As we have already established that GST is changing the way how tax is paid, businesses will now have to employ tax professionals to be GST-complaint. GST eliminates the cascading effect of tax: GST is a comprehensive indirect tax that was designed to bring the indirect taxation under one umbrella. More importantly, it is going to eliminate the cascading effect of tax that was evident earlier. Cascading tax effect can be best described as 'Tax on Tax'.

\section{REFERENCES}

[1]. Agrawal, A. (2011). India's Goods and Services Tax a Primer. STCI Primary Dealer Ltd, pp. 1-11

[2]. I.M Pandey, (2009). Financial Management, 9th edition. Vikas publishing house Pvt ltd

[3]. M.Y Khan, P.K Jain. (2009). Management Accounting, $3^{\text {rd }}$ edition. Tata McGraw-Hill publishing Co.ltd

[4]. Mehra, P. (2015). Modi governments' model for GST may not result in significant growth push. Hindu

[5]. Mitra, S. (2011). The Indian Tax System and its Reform. ASCI Journal of Management, 40(2), pp. 128-138.

[6]. R. K. Jain. (2018\&19). GST Tariff of India $4^{\text {th }}$ Edition. Centex Publications

[7]. S.N.Maheshwari.(2006).Financial Management, Sultan Chand\& Sons, Educational Publishers, New Delhi

[8]. Varshney, A. (2007). India's Democratic Challenge, Foreign Affairs. 86(2), pp. 93-106
Cite this article as :

Dr. Nalla Bala Kalyan, Toopalli Sirisha, 'Analysis of Financial Statement of NRC Agro with Special Reference to Goods and Service Tax', International Journal of Scientific Research in Science and Technology(IJSRST),Print ISSN : 2395-6011, Online ISSN : 2395-602X,Volume 6 Issue 1, pp.45-65, January-February 2019.

Available at doi :

https://doi.org/10.32628/IJSRST196110

Journal URL : http://ijsrst.com/IJSRST196110 